\title{
High Frequency of Multidrug Resistant Urinary Isolates in Pregnant Women in a Tertiary Care Hospital of Nepal
}

\author{
Bhandari Pashupati ${ }^{1 *}$, Dipak Raj Joshi ${ }^{2}$, Sharma Khem Raj ${ }^{2}$, Khanal Santosh ${ }^{1}$, Acharya \\ Ganesh $^{3}$, Adhikari Nabaraj ${ }^{2}$ \\ ${ }^{1}$ Department of Microbiology, National College (NIST), Khusibu, Kathmandu, Nepal \\ ${ }^{2}$ Department of Microbiology, Kantipur College of Medical Sciences, Sitapaila, Kathmandu, Nepal \\ ${ }^{3}$ Department of Pathology Laboratory, Paropakar Maternity and Women's Hospital, Kathmandu, Nepal
}

Received: November 15, 2016; Accepted: December 25, 2016; Published: January 2, 2017

*Corresponding author: Bhandari Pashupati, Department of Microbiology, National College (NIST), Khusibu, Kathmandu, Nepal; E-mail: pashupati.microxpress@gmail.com

\begin{abstract}
Introduction: Urinary tract infection (UTI) is a common infection during pregnancy with frequency ranging from 5-20\%. Bacteriuria in pregnancy whether asymptomatic or symptomatic if untreated may lead to pyelonephritis which may result in abortion, premature delivery, low weight birth and even still birth. This study was conducted to identify the etiological agents and assess antibiotic resistance pattern of bacterial urinary isolates in patients attending Paropakar Maternity and Women's Hospital, Kathmandu, Nepal.
\end{abstract}

Methods: Urine samples were collected and processed using standard microbiological procedures and bacterial isolates were identified by morphological test, Gram staining and different biochemical tests namely catalase, oxidase, motility, indole and $\mathrm{H}_{2} \mathrm{~S}$ production, citrate and urease enzyme production and triple sugar iron agar test. Antibiotic susceptibility test was performed by KirbyBauer disk diffusion method as recommended by Clinical Laboratory Standard Institute.

Results: From a total of 653 urine samples processed, 112 different bacteria were isolated. Most common gram negative isolate was Escherichia coli with 71/112 (63.4\%) followed by Klebsiella pneumoniae with 9/112 (8\%) isolates. Similarly, 5/171 (4.5\%) isolates each of $P$. mirabilis and $P$. vulgaris were found while $P$. aeruginosa isolates was $3 / 171$ (2.7 \%) isolated in lowest frequency in the study. Coagulase negative Staphylococci was most common gram positive isolate with 9/171 (8\%) frequency. Ninety percent of Gram negative isolates were resistant to Nalidixic acid followed by Ampicillin and Cephalexin with $87.1 \%$ and by $82.8 \%$ respectively and MDR was found in $73.2 \%$ of total 112 bacterial isolates. Increasing trimester of pregnancy was found statistically significant in terms of increased UTI frequency $(p=0.0001)$.

Conclusion: High proportion of multidrug resistant urinary isolates was found in pregnant women. Therefore early detection of antimicrobial susceptibility pattern of theses isolates and routine tests to identify potential cause of MDR should be practiced.

Keywords: Multidrug-resistance; Pregnancy; Urinary tract infection

\section{Introduction}

Urinary Tract Infection (UTI) is one of the most common bacterial infections accounting for about $25 \%$ of all types of infection in human and approximately $10 \%$ of the humans acquire UTI at some time during their lifetime [1]. The Incidence of UTI is age and sex dependent and it occurs with higher frequency in female than in men because of shorter urethra and close proximity of urinary tract to anus and most prevalent age group experiencing UTI in females is 21-30 years age [2].

Anatomical changes, for example ureteral dialation, increased bladder volume along with decreased bladder and ureteral tone will contribute to urinary stasis and ureterovesical reflux, in addition with physiological changes like glycosuria, during pregnancy which encourages bacterial growth in the urine thus leading to development of UTI [3,4]. Among the pregnant women approximately 4 to $10 \%$ will have asymptomatic bacteriuria, and 1 to $4 \%$ will develop acute cystitis and 1 to $2 \%$ may develop severe acute pyelonephritis during the second half of pregnancy 5 . Major bacteria associated with UTI includes, E. coli, Klebsiella spp, Citrobactor spp, Enterobacter spp, Proteus spp, Pseudomonas aeruginosa, Staphylococcus aureus, coagulase negative Staphylococci where E. coli alone accounts for 80 $90 \%$ infections [5], about $85 \%$ of community acquired UTIs, $50 \%$ of nosocomial UTIs and more than $80 \%$ of uncomplicated pyelonephritis [6].

Untreated asymptomatic bacteriuria increases the frequency of premature delivery, neonates with low birth weight and it is also likely to cause acute pyelonephritis at a rate of 20 to $30 \%$ [7]. Studying antibiotic sensitivity profile of urinary isolates helps us to select drugs for individual patient treatment so that recurrence could be prevented. Additionally, resistance pattern of these organisms against drugs in clinical practice can be determined which will aid in prevention of emerging multidrug resistant strains. 


\section{Methodology}

This cross sectional study was conducted from August 2015 to April 2016 at Paropakar Maternity and Women's Hospital, Kathmandu, Nepal.

\section{Sample size}

A total of 653 different urine samples from pregnant women received in hospital microbiology laboratory were processed in the study.

\section{Sample Collection and Processing}

Patient were requested to collect Mid Stream Urine (MSU) sample in a sterile urine container after giving proper instruction to collect it and thus collected samples were immediately processed in laboratory. In case of delay in processing for more than 2 hours, boric acid (1.8\%) was added as a preservative $[8,9]$. As samples received in microbiology laboratory for routine culture and sensitivity test was only processed during this study, no patient consent was required.

\section{Microscopic Examination}

Urine sample was first centrifuged at $2500 \mathrm{rpm}$ for $5 \mathrm{~min}$ and supernatant was decanted. A drop of sediment was placed on a clean glass slide, covered with cover slip and observed under microscope to observe pus cells, red blood cells, epithelial cells, casts, crystals, yeast-like cells. Pus cells > 5/HPF were also considered significant for infection [10].

\section{Culture}

Urine specimens were cultured by semi-quantitative culture technique. A loop full of well-mixed and uncentrifuged samples was inoculated using standard calibrated loop onto Blood Agar (BA) and Macconkey Agar (MA) plates and aerobically incubated at $37^{\circ} \mathrm{C}$ for $24 \mathrm{~h}$. After overnight incubation, colony count yielding bacterial growth of $\geq 10^{5} \mathrm{CFU} / \mathrm{ml}$ was taken as being significant [11]. If the culture indicates presence of two uropathogens both showing significant growth, definitive identification and antimicrobial susceptibility testing of both were performed whereas in cases of $\geq 3$ pathogens, it was reported as multiple bacterial morphotypes and asked for appropriate recollection with timely delivery to laboratory [12].

\section{Identification of Isolates}

At first colony characteristics of isolated bacteria was observed on agar plates and Gram staining was done. Gram positive isolates were identified by performing catalase, oxidase, coagulase, and optochin sensitivity tests while for Gram negative bacteria, different biochemical tests, catalase, oxiadse, motility, hydrogen sulphide and indole production, citrate utilization, MR/ VP, urea hydrolysis, and triple sugar iron utilization were done and then identified based on their results [13].

\section{Antimicrobial Susceptibility Testing}

Antimicrobial susceptibility test was performed by disc diffusion method as recommended by Clinical Laboratory Standard Institute (CLSI), 2012. Four to five different colonies of test organisms were touched with sterile loop and mixed with 2 $\mathrm{ml}$ of sterile saline and vortexed to create a smooth suspension. Turbidity of this solution was adjusted to a 0.5 McFarland standard which has corresponding bacterial concentration of approximately 150 million/ml. A sterile swab was dipped into the suspension, firmly pressed to remove excess fluid, and plated on Muller Hinton Agar (MHA). Discs were applied on MHA plates and incubated at $37^{\circ} \mathrm{C}$ for 24 hours. Zone of inhibition was measured and interpreted using the standard chart and organisms reported as susceptible, intermediate or resistant accordingly [14]. Following antibiotic discs were used Ampicillin $(10 \mu \mathrm{g})$, Cephalexin $(30 \mu \mathrm{g})$, Ciprofloxacin $(5 \mu \mathrm{g})$, Cotrimoxazole $(25 \mu \mathrm{g})$, Gentamycin $(10 \mu \mathrm{g})$, Nalidixic acid $(30 \mu \mathrm{g})$, Nitrofurantoin $(300 \mu \mathrm{g})$, Norfloxacin $(10 \mu \mathrm{g})$, Olfoxacin $(10 \mu \mathrm{g})$.

\section{Statistical Analyses}

Data analyses were performed using Statistical Package for Social Science (SPSS) version 16.0 (SPSS Inc., Chicago, IL, USA) and Microsoft excel 2007 and correlation analysis was performed to determine relation between two or more variables.

\section{Results}

\section{Socio-demographic Characteristics}

A total of 653 pregnant women were enrolled in this study with the age ranges between 17-30 years and all of them were married. Of considered variables, increasing trimester was significantly associated with UTI while showing no association with age (Table 1).

\section{Pyuria and Hematuria}

Of 653 total urine samples, 123 (24.6\%) showed significant pyuria (> $5 \mathrm{WBC} / \mathrm{hpf}$ ), similarly $104(15.9 \%)$ of samples showed significant haematuria (> 3RBC/hpf) (Table 2).

\section{Bacterial Growth Pattern}

Table 1: Prevalence of UTI and demographic characteristic of study population $(\mathrm{N}=653)$.

\begin{tabular}{|c|c|c|c|c|c|}
\hline \multirow{2}{*}{$\begin{array}{c}\text { Character- } \\
\text { istics }\end{array}$} & $\begin{array}{c}\text { Number } \\
\text { tested }\end{array}$ & \multirow{2}{*}{\multicolumn{2}{|c|}{ Bacterial growth }} & \multirow{2}{*}{$\begin{array}{c}\begin{array}{c}\text { Chi- } \\
\text { square }\end{array} \\
\left(\mathrm{X}^{2}\right)\end{array}$} & \multirow[t]{2}{*}{ P-value } \\
\hline & (\%) & & & & \\
\hline \multirow{2}{*}{ Age (years) } & & Positive & Negative & \multirow{5}{*}{1.873} & \multirow{5}{*}{0.862} \\
\hline & & $(\%)$ & (\%) & & \\
\hline $17-20$ & $484(74.1)$ & 85 (17.5) & 399 (82.5) & & \\
\hline $21-25$ & 155 (23.7) & $24(15.4)$ & 131 (84.6) & & \\
\hline $26-30$ & $14(2.2)$ & $3(21.4)$ & 11 (78.6) & & \\
\hline \multicolumn{6}{|c|}{ Trimester } \\
\hline $\mathbf{1}^{\text {st }}$ & 183 & 29 (15.8) & $154(84.2)$ & & \\
\hline $2^{\text {nd }}$ & 290 & 61 (21.1) & 229 (78.9) & & \\
\hline $3^{\text {rd }}$ & 180 & $22(27.5)$ & $158(72.5)$ & 13.256 & 0.0001 \\
\hline
\end{tabular}


112 (17.2\%) samples showed significant growth and remaining 541 showed either no growth as shown in Figure1.

\section{Frequency of Bacterial Uropathogens}

Of all the bacteria isolated ( $\mathrm{n}=112)$, Gram-negative bacteria were more prevalent 93 (83.1\%) than Gram-positive bacteria 19 (16.9\%). The most common isolate was E. coli 71 (63.4\%), followed by Proteus spp 10 (9\%), coagulase negative Staphylococci and $K$. pneumoniae with 9 (8\%) isolates each (Table 3).

\section{Antimicrobial Susceptibility Pattern of Gram Negative Bacteria}

Among gram negative isolates, Nitrofurantoin was found to be most sensitive (93.5\%) drug with followed by Gentamicin (80.6\%), Ofloxacin (77.4\%), Norfloxacin (68.8\%), Ciprofloxacin $(68.6 \%)$ and Cotrimoxazole (52.6\%) each (Table 4) and individual antibiotic susceptibility percentage shown by E. coli, $K$ pneumoniae and Proteus vulgaris is presented in table 5.

\section{Antimicrobial Susceptibility Pattern of Gram Positive Bacteria}

Nitrofurantoin, Norfloxin and Ofloxacin were found to be the drug of choice with a susceptibility of $94.73 \%, 78.94 \%$ and $78.94 \%$ respectively (Table 6).

\section{Multiple Drug Resistance Patterns of the Isolates}

Among the total 112 isolates, multi drug resistance (MDR = resistance in $\geq 3$ drugs) was recorded in 82 (73.2\%) bacteria. MDR was observed in E coli, Klebsiella spp, Pseudomonas and Proteus spp only (Table 7).

\section{Discussion}

Different physiological changes like increased glucose, amino acids, vitamins content of the urinary tract along with other

Table 2: Frequency of pus and red blood cells on microscopic observation.

\begin{tabular}{|l|c|c|}
\hline Microscopic observation & Frequency (n) & Percentage (\%) \\
\hline Pyuria (significant $>$ 5/ hpf) & 123 & 24.6 \\
\hline Haematuria (significant $>$ 3/ hpf) & 6 & 5.77 \\
\hline
\end{tabular}

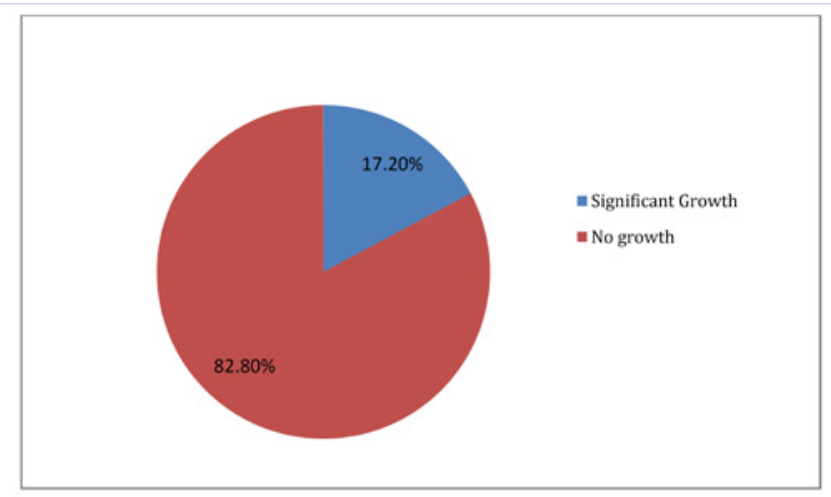

Figure 1: Growth pattern of bacterial isolates
Table 3: Frequency of different bacterial isolates

\begin{tabular}{|l|c|c|}
\hline \multicolumn{1}{|c|}{ Bacteria } & Frequency (n) & Percentage (\%) \\
\hline Gram positive cocci & $\mathbf{1 9}$ & $\mathbf{1 6 . 9}$ \\
\hline CoNS & 9 & 8 \\
\hline S. faecalis & 7 & 6.3 \\
\hline S. aureus & 3 & 2.7 \\
\hline Gram negative rods & $\mathbf{9 3}$ & $\mathbf{8 3 . 1}$ \\
\hline E. coli & 71 & 63.4 \\
\hline K. pneumoniae & 9 & 8 \\
\hline P. vulgaris & 5 & 4.5 \\
\hline P. mirabilis & 5 & 4.5 \\
\hline P. aeruginosa & 3 & 2.7 \\
\hline Total & $\mathbf{1 1 2}$ & $\mathbf{1 0 0} \%$ \\
\hline
\end{tabular}

Table 4: Antibiotic susceptibility pattern of gram negative isolates (n =93)

\begin{tabular}{|l|c|c|c|c|}
\hline \multirow{2}{*}{ Antibiotics used } & \multicolumn{2}{|c|}{ Sensitive } & \multicolumn{2}{c|}{ Resistant } \\
\cline { 2 - 5 } Ampicillin & No. & $\%$ & No. & $\%$ \\
\hline Cephalexin & 12 & 12.9 & 81 & 87.1 \\
\hline Ciprofloxacin & 16 & 17.2 & 77 & 82.8 \\
\hline Cotrimoxazole & 62 & 66.66 & 31 & 33.34 \\
\hline Gentamicin & 79 & 52.68 & 44 & 47.32 \\
\hline Nalidixic acid & 9 & 90.64 & 18 & 19.36 \\
\hline Nitrofurantoin & 87 & 93.54 & 84 & 90.33 \\
\hline Norfloxacin & 64 & 68.81 & 6 & 6.46 \\
\hline Ofloxacin & 72 & 77.41 & 21 & 22.29 \\
\hline
\end{tabular}

favorable anatomical changes during pregnancy fosters the bacterial growth during pregnancy [9]. Prevalence of urinary tract infection in this study was $17.2 \%$ which is higher than prevalence of UTI reported in another research (9.8\%) [15], but lower than study in Valley Maternity hospital, Kathmandu (44.6\%) [16]. This variation could be due to difference in the environment, social habit of community and standard of personal hygiene [17]. All patients in our study were in age group 17-30 which corresponds to another study [18] and illustrates active pregnancy age group in Nepalese woman is in between these years.

There was significant positive association between increasing trimester of pregnancy with increasing UTI frequency while patients having at least higher secondary level of education experienced lower episodes of frequency was statistically significant. Similar to our findings, other studies have also shown significant statistical relationship between among these variables $[19,20]$. Maintaining hygienic standards, sanitation practices and keeping the tract clean greatly reduce the risk to acquire urinary tract infections during pregnancy.

Gram negative bacteria were more prevalent (83.1\%) than Gram positive bacteria (16.9\%). Comparable finding were reported from India (78\%) and Pakistan (81.2\%) [7,21]. 
Table 5: Individual antibiotic susceptibility pattern of E. coli, K. pneumoniae and P. vulgaris

\begin{tabular}{|c|c|c|c|c|c|c|}
\hline \multirow[b]{2}{*}{ Antibiotics } & \multicolumn{2}{|c|}{ E. $\operatorname{coli}(n=71)$} & \multicolumn{2}{|c|}{ K. pneumoniae $(\mathrm{n}=9)$} & \multicolumn{2}{|c|}{ P. vulgaris $(\mathrm{n}=5)$} \\
\hline & $\begin{array}{c}\text { Resistance } \\
\text { n (\%) }\end{array}$ & $\begin{array}{c}\text { Sensitive } \\
\text { n (\%) }\end{array}$ & $\begin{array}{c}\text { Resistance } \\
\text { n (\%) }\end{array}$ & $\begin{array}{c}\text { Sensitive } \\
\text { n(\%) }\end{array}$ & $\begin{array}{c}\text { Resistance } \\
\text { n (\%) }\end{array}$ & $\begin{array}{c}\text { Sensitive } \\
\text { N (\%) }\end{array}$ \\
\hline Ampicillin & $61(85.91)$ & $10(14.09)$ & $8(88.89)$ & $1(11.11)$ & $4(80)$ & $1(20)$ \\
\hline Cotrimoxazole & 33 (46.47) & $38(53.53)$ & $6(66.67)$ & $3(33.37)$ & $1(20)$ & $4(80)$ \\
\hline Ciprofloxacin & $21(26.76)$ & $50(73.24)$ & $5(55.55)$ & $4(45.45)$ & $2(40)$ & $3(60)$ \\
\hline Gentamicin & 15 (21.12) & $56(78.880$ & $0(0)$ & $9(100)$ & $1(20)$ & $4(80)$ \\
\hline Ofloxacin & 17 (23.94) & $54(76.06)$ & $3(33.33)$ & $6(66.67)$ & $1(20)$ & $4(80)$ \\
\hline Cephalexin & 58 (81.69) & $13(18.31)$ & 8 (88.89) & $1(11.11)$ & $4(80)$ & $1(20)$ \\
\hline Norfloxacin & $18(25.35)$ & $53(74.65)$ & $8(88.89)$ & $1(11.11)$ & $1(20)$ & $4(80)$ \\
\hline Nitrofurantoin & $5(7.04)$ & $66(92.96)$ & $0(0)$ & $9(100)$ & $0(0)$ & $5(100)$ \\
\hline Nalidixic acid & $66(92.95)$ & $5(7.05)$ & $8(88.89)$ & $1(11.11)$ & $5(100)$ & $0(0)$ \\
\hline
\end{tabular}

Table 6: Antibiotic susceptibility pattern of gram positive isolates $(\mathrm{n}=$ 19)

\begin{tabular}{|l|c|c|c|c|}
\hline \multirow{2}{*}{ Antibiotic used } & \multicolumn{2}{|c|}{ Sensitive } & \multicolumn{2}{c|}{ Resistant } \\
\cline { 2 - 5 } & No. & $\%$ & No. & $\%$ \\
\hline Ampicillin & 4 & 21.05 & 15 & 78.95 \\
\hline Cotrimoxazole & 12 & 63.15 & 7 & 31.59 \\
\hline Ciprofloxacin & 10 & 52.63 & 9 & 42.11 \\
\hline Gentamicin & 16 & 84.21 & 3 & 15.79 \\
\hline Ofloxacin & 15 & 78.94 & 4 & 15.8 \\
\hline Cephalexin & 7 & 36.84 & 12 & 57.9 \\
\hline Norfloxacin & 15 & 78.94 & 4 & 15.8 \\
\hline Nitrofurantoin & 18 & 94.73 & 1 & 5.27 \\
\hline Nalidixic acid & 4 & 21.05 & 15 & 78.95 \\
\hline
\end{tabular}

Table 7: Frequency of multi drug resistant isolates

\begin{tabular}{|l|c|c|c|}
\hline \multicolumn{1}{|c|}{ Organisms } & Total isolates & MDR Frequency & MDR Frequency \\
\hline P. aeruginosa & 3 & 3 & 100 \\
\hline P. mirabilis & 5 & 5 & 100 \\
\hline E. coli & 71 & 64 & 90.14 \\
\hline K. pneumoniae & 9 & 7 & 77.78 \\
\hline P. vulgaris & 5 & 3 & 60 \\
\hline
\end{tabular}

Gram negative bacteria have several host adhesion factors that facilitates unique adhesion and adherence to host epithelial cells thereby preventing removal during urination and ultimately results invasion and pyelonephritis [22].

We have found E. coli as the most common isolates (63.4\%) followed by Proteus spp (9\%). In concurrent to our study, study from other Maternity hospitals of Kathmandu [3] and Pokhara [10] shown E. coli as dominant pathogen causing urinary tract infection during pregnancy. E. coli is the most common microorganism in the vaginal and rectal area and due to anatomical and functional changes and difficulty of maintaining personal hygiene during pregnancy may increase the risk of acquiring UTI from E. coli $[2,17]$.

Antibiotic resistant caused multi drug resistant organisms have severely impaired available treatment options which might lead to the situation to rely only on certain antibiotics like fosfomycin, colistin and carbapenems [23,24]. We have found that Gram negative bacteria were most resistant to Cotrimoxazole (47.32\%), quinolone [Ciprofloxacin and Ofloxacin (31.32\% and $22.59 \%$ respectively)], and Nitrofurantoin $(6.46 \%)$. In contrary, another study showed high resistance to different classes of antibiotics used: Co-trimoxazole (86.8\%), quinolone (Ciprofloxacin and Ofloxacin 92.6\%) in each and Nitrofurantoin (17.6\%) [23]. Local resistance pattern, nature of patients (ICU or OPD), easy availability and indiscriminate use of common drugs might account for this difference.

Our study showed that, resistant rate of Gram positive bacteria against Nitrofurantoin (5.27\%), and Ofloxacin and Norfloxacin was $21.06 \%$ each. Generally, Gram positive bacteria have less resistance mechanism than gram negative bacteria as they are more easily inhibited by body's defense system than later, and also by routine drugs [24].

Multidrug resistant (resistance to $\geq 3$ different structural drugs) was reported in $73.2 \%$ of isolates while in another study carried out at Kathmandu Model Hospital from Kathmandu in 2012 showed 41\% MDR isolates [23]. This clearly indicates rise in MDR isolates in uropathogens and could be consequence of indiscriminate antibiotic use and abuse [25]. High frequency of MDR is alarming issue as this leaves us with potentially very few antibiotics to treat such MDR infected patients and risk patient lives. Drugs like ceftriaxone or carbapenems for example meropenem or imipenem could be the drug of choice in treating such multi drug resistant urinary bacterial isolates [26].

\section{Conclusion}


We found high prevalence of multidrug resistant uropathogens and resistant rate was particularly higher against cotrimoxazole and quinolone antibiotics thus using those antibiotics for empirical therapy of UTI is discouraged. Nitrofurantoin, ceftriaxone and carbapenems could be better options for empirical therapy in such cases.

\section{Competing interests}

Authors declare that there is no competing interest.

\section{Acknowledgements}

We are thankful to all patients who participated in this study and staff of Paropakar Maternity and Women's Hospital, Kathmandu, Nepal. Our sincere thank goes to Dr. Megha Raj Banjara for his contribution in correction of this manuscript.

\section{References}

1. Karki A, Tiwari BR, Pradhan SB. Study of bacteria isolated from urinary tract infections and their sensitivity pattern. J Nepal Med Assoc. 2004;43(154):200-203

2. Baral P, Neupane S, Marasini BP, Ghimire KR, LekhakB, Shrestha B. High prevalence of multi drug resistance in bacterial uropathogens from Kathmandu, Nepal. BMC Res Notes. 2012;5:38. doi: 10.1186/17560500-5-38

3. Jha N, Bapat SK. A study of sensitivity and resistance of pathogenic microorganisms causing UTI in Kathmandu valley. Kathmandu Univ Med J (KUMJ). 2005;3(2):123-9.

4. Das RN, Chandrashekhar TS, Joshi HS, Gurung M, Shrestha N, Shivananda PG. Frequency and susceptibility profile of pathogens causing urinary tract infections at a tertiary care Hospital in western Nepal. Singapore Med J. 2006;47(4):281-285. https://www.ncbi.nlm. nih.gov/pubmed/16572238.

5. Akram M, Shahid M, Khan AU. Etiology and antibiotic resistance patterns of community-acquired urinary tract infections in JNMC Hospital Aligarh. India. Ann Clin Microbiol Antimicrob. 2007;6:4.

6. Bergerson MG. Treatment of Pyelonephritis in Adults. Med Clin North Am. 1995;75:619-49.

7. Manjula NG, Girish CM, Shripad AP, Subhashchandra MG, Channappa TS. Incidence of urinary tract infections and its aetiological agents among pregnant romen in Karnataka Region. Adv Microbiol. 2013;3:473-78

8. Pokhrel BM. A handbook of clinical microbiology. $1^{\text {st }}$ ed. Kathmandu. Graphic Plus Printer. 2012

9. Asscher AW, Sussman M, Waters WE, Davis RH, Chick S. Urine as a medium for bacterial growth. Lancet. 1966;2(7472):1037-41.

10.Gupta UP, Jaiswal S, Thapa L, Parajuli M, Nepali S. Prevalence of urinary tract infection among suspected female patients attending Manipal teaching hospital, Pokhara, Nepal. RRJoMV. 2013;3(2):223036.

11.Tamalli M, Bioprabhu S, Alghazal MA. Urinary tract infection during pregnancy at Al-khoms, Libya. Int J Med Med Sci. 2013;3(5):455-59.

12.Isenberg HD. Clinical Microbiology Procedures Handbook. $2^{\text {nd }}$ ed. Washington, D.C. ASM Press. 2004.
13. Cheesbrough M. District Laboratory Practice in Tropical Countries. $2^{\text {nd }}$ ed. Part 2. Cambridge University Press, 2006.

14. Clinical Laboratory Standard Institute (CLSI): Performance standards for antimicrobial susceptibility testing; Twentysecond informational supplement document. Wayne, PA: CLSI: 2012;M100-S20.

15. Marahatta R, Dhungel BA, Pradhan P, Rai SK, Choudhury DR. Asymptomatic bacteriurea among pregnant women visiting Nepal Medical College Teaching Hospital, Kathmandu, Nepal. Nepal Med Coll J. 2011;13(2): 107-10.

16. Parajuli S, Thapa S. Microbiology of urinary tract infection and status of urinary isolates in pregnant women. Medical journal of Shree Birendra hospital. 2014:13(2):20-24

17. Alemu A, Moges F, Shiferaw Y, Tafess K, Kassu K, Anagaw B, et al. Bacterial profile and drug susceptibility pattern of urinary tract infection in pregnant women at University of Gondar Teaching Hospital, Northwest Ethiopia. BMC Res Notes. 2012;5:197. doi: 10.1186/1756-0500-5-197.

18. Subedi M, Basnyat SR. Urinary tract infection in pregnancy and its correlation with Nitrite test. J Nepal Health Res Council. 2009;1(15):8083.

19. Haider G, Zehra N, Munir AA, Haider A. Risk factors of urinary tract infection in pregnancy J Pak Med Assoc. 2010;60(3):213-6.

20. Okonko IO, Ijandipe LA, Ilusanya OA , Donbraye-Emmanuel OB, Ejembi J, Udeze AO et al. Incidence of urinary tract infection (UTI) among pregnant women in Ibadan, South-Western Nigeria. Afr. J. Biotechnol.2009;8(23):6649-57.

21. Sheikh MA, Khan MS, Khatoon A, Arain GM. Incidence of urinary tract infection during pregnancy. East Mediterr Health J. 2000;6(2-3):26571.

22. Amiri FN, Rooshan MH, Ahmady MH, Soliamani MJ. Hygiene practices and sexual activity associated with urinary tract infection in pregnant women. East Mediterr Health J. 2009;15(1):104-10.

23. Mohammad M, Mahdy ZA, Omar J, Maan N, Jamil MA. Laboratory aspects of asymptomatic bacteriuria in pregnancy. Southeast Asian J Trop Med Public Health. 2002;33(3):575-80.

24. Marziyeh A, Lavasani Z, Norouzirad R, Najibpour R, Mohamadpour M, Nikpoor AR et al. Prevalence of urinary tract infection among pregnant women and its complications in their newborns during the birth in the hospitals of Dezful City, Iran, 2012 - 2013. Iran Red Crescent Med J. 2015;17(8):e26946. doi: 10.5812/ircmj.26946.

25. Albrich WC, Monnet DL, Harbarth S. Antibiotic selection pressure and resistance in Streptococcus pneumoniae and Streptococcus pyogenes. Emerg Infect Dis. 2004;10(3):514-7.

26. Christensen B. Which antibiotics are appropriate for treating bacteriuria in pregnancy? J Antimicrob Chemother 2000;46:29-34.s 